session, attendees will work with well-known leaders in cardiothoracic surgery and NIH Staff to achieve the following:

- Create career development and training grants

- Analyze outcomes research and clinical research networks

- Assess the structure and components of a grant

- Identify extramural program and funding opportunitiesNCI and NHLBI

- Understand the steps to becoming an NIH investigator

The deadline for registration is Friday, February 6, 2013. For additional information on the workshop program, housing, and to register, please visit www.aats.org.

\section{AATS Leadership Academy Applications}

Friday, April 24, 2015, Seattle, WA

For current and future CTS Division Chiefs/Department Chairs (Immediately prior to the AATS Annual Meeting)

The 2015 AATS Leadership Academy is an intensive, didactic, and interactive program for up to 20 surgeons who have demonstrated significant promise as potential future division chiefs or who have recently assumed the role of division chief. The goal of this program is to provide participants with the administrative, interpersonal, mentoring, and negotiating skills necessary to serve successfully as a division chief while also offering an opportunity to network with well-known thoracic surgical leaders who might subsequently serve as personal mentors after the conclusion of the program.

For additional information regarding the Academy, please visit www.aats.org. Interested applicants should meet the following qualifications before applying:

- Achieved the rank of Associate Professor

- Active/successful clinical surgeon

- Evidence of local institutional and/or state/regional leadership ability

- Evidence of academic productivity including peerreviewed publications and presentations at regional or national scientific meetings

- Funded research is preferable but not essential

Applications for consideration must be submitted electronically at www.aats.org by November 30, 2014. Participants will be selected by the Leadership Academy Committee and notified no later than February 5, 2015.

\section{The American Association for Thoracic Surgery Journals}

\section{Seminars in Thoracic and Cardiovascular Surgery and Operative Techniques in Thoracic and Cardiovascular Surgery}

Important papers in the Seminars in Thoracic and Cardiovascular Surgery and Operative Techniques in Thoracic and Cardiovascular Surgery that correspond to the areas of interest in the Journal:

\section{GENERAL THORACIC SURGERY}

Thoracic Oncology:

Seminars: State of the Art: Present status of lymph node mapping for lung cancer-Yolonda Colson. Expected publication December 2014.

Seminars: State of the Art: The new Lung Cancer Adenocarcinoma: Classification and prognosis what the surgeon should know-Prasad Adusumilli. Expected publication December 2014.

Seminars: Current Readings: Management of N2 Disease for Lung Cancer-Dennis Wigle. Semin Thorac Cardiovasc Surg. 2014 Spring;26(1):67-70.

Seminars: Current Readings: Computed Tomography Screening for Lung Cancer-Phillip Boiselle. Semin Thorac Cardiovasc Surg. 2013 Winter;25(4):323-7.
Seminars: Current Readings: Blood-based Biomarkers for Lung Cancer-William Rom. Semin Thorac Cardiovasc Surg. 2013 Winter;25(4):328-34.

Seminars: State of the Art: Non-Small Cell Lung Cancer Immunotherapy-Nagashree Seetharamu. Semin Thorac Cardiovasc Surg. 2014 Spring;26(1):26-35.

Seminars: News and Views: Novel induction therapies for pleural mesothelioma-Marc de Perrot. Expected publication December 2014.

Seminars: Current Readings: Ablation techniques for Pulmonary Mestastases-Robert Suh. Expected publication December 2014.

Op Techs: Technique of Video-Assisted Thoracoscopic Left Pneumonectomy-Todd Demmy. Oper Tech Thorac Cardiovasc Surg. 2013 Winter;18(4):264-74.

Op Techs: Minimally Invasive Ivor-Lewis Esophagectomy-David Jones. Oper Tech Thorac Cardiovasc Surg. 2013 Winter; 18(4):254-63.

Other Thoracic Surgical Papers:

Seminars: News and Views: Modern Management of Empyema Thoracis-H. Hofmann. Semin Thorac Cardiovasc Surg. 2013 Winter;25(4):292-9.

Seminars: Current Readings: Surgical Repair Experience of Congenital Chest Wall Deformities-Eugene Kim. Semin Thorac Cardiovasc Surg. 2013 Winter;25(4):317-22. 